\title{
Global Supply Chains and Technology Upgrading in the ASEAN- China Relationship: Is China Eating ASEAN's Lunch?
}

\author{
Shiau Ping Chew \\ Mohamed Aslam Gulam Hassan ${ }^{b}$ \\ Mario Arturo Ruiz Estradac \\ University of Malaya
}

\begin{abstract}
While Asia's economic growth has been defined by technological advances, China stands out in its proactive role of the state and its dominance of global supply chains. As China strengthens its technological capability, this dominance is also translating into the country capturing more value added. This has implications for other participants of its supply chains in terms of intermediate inputs and value addition of supply chain activities. Revealed comparative advantage indicators reveal that the Association of Southeast Asian Nations' (ASEAN) middle-income countries are no match for China's technological prowess. ASEAN's domestic contribution to value added has also not gained much over the years, while a rising share of Chinese inputs among intermediate goods imports embodied in ASEAN's exports has seen China displacing other import sources. The growing importance of Chinese inputs suggests not only China's ability to take over an increasing part of supply chains in this region but also raises the possibility that it is able to establish its own supply chains that are linked to Southeast Asia. Whether ASEAN countries are able to capture more value added will depend on their ability to advance their technological capabilities.
\end{abstract}

Keywords: ASEAN, China, supply chains, technological capability, value-added JEL classification: F10, F12, F15

\section{Introduction}

Although several mainstream approaches exist to explain industrial catch-up by developing countries, the economic rise of Asia is associated with technological advances that is consistent with the new evolutionary growth theory that emphasises the learning process (Cimoli, Dosi, \& Stiglitz, 2009) and latecomer advantages (Gerschenkron, 1962), while in contravention of earlier theories of the orderly growth (Akamatsu, 1962; Rostow, 1960). On the back of a host of strategies explaining such advances, such as "windows of opportunity" (Perez \& Soete, 1988), stages of catchup (Kim, 1997) and path-following and leapfrogging (Lee \& Lim, 2001), economies like

a Faculty of Economics and Administration, University of Malaya, 50603 Kuala Lumpur, Malaysia. Email: ikebukuru@hotmail.com, shiauping@siswa.um.edu.my (Corresponding author)

b Faculty of Economics and Administration, University of Malaya, 50603 Kuala Lumpur, Malaysia. Email: maslam@um.edu.my

c Social Wellbeing Research Centre (SWRC), Faculty of Economics and Administration, University of Malaya. Email: marioruiz@um.edu.my 
South Korea and Taiwan have risen to developed country status, while their technology is second to none. Even as their development models receive close scrutiny, a rising but economically lagging China has begun to pose a technological challenge, using a model that differs substantially from those deployed by these economies. An important departure for China is the much more proactive role of the state in driving innovation, and the very size of the country which allows for multiple models to be simultaneously deployed (Cheong, Wong, \& Goh, 2016; Li, 2018).

Another area of difference between China and earlier models is its dominance over global supply chains (GSCs) that, because of the importance of the Chinese market, often end in China (see, for instance, Economist, 2018; Stevenson, 2018). Now acknowledged as central to globalisation and with the most recent development in trade, GSCs relationship with China has been characterised as: (1) China's industrial clusters like the Pearl River Delta having unmatched comparative advantage, in terms of enterprise concentration and other agglomeration economies, abundant supply of talent, strong physical infrastructure, access to venture capital complemented by strong state support (Economist, 2018; Gereffi \& Lee, 2012)1 ${ }^{1}$, (2) the country's advantage eroded somewhat by rising labour costs, eliciting responses that include automation and efforts to move up the value chain through branding and technology acquisition, and (3) despite its heavy commitment to GSCs, China is not earning a great deal of value added in the process. The miniscule US\$6.54 value added China earns from the US\$194 iPhone is now legend (Gereffi \& Lee, 2012). ${ }^{2}$ It also served to confirm the widespread belief that as "factory to the world", China's comparative advantage lay in its highly productive workforce. That the country also makes substantial licensing and royalty payments to foreign country firms feeds on the perception from the iPhone story that innovation in China is modest. ${ }^{3}$ Juxtaposed against these dramatic statistics is the equally significant observation that China is the largest electronics export source in Asia, contributing $40.3 \%$ of the total electronics exports of Asia in 2016 (HKTDC, 2017a: 2). At the same time, the majority of export processing enterprises are earning only meagre returns (HKTDC, 2017b: 1) which although seeming to confirm the earlier account of low value-added output, have also been attributable to aggressive pricing by Chinese enterprises hungry for business. However, this has begun to change. Chinese enterprises are reportedly upgrading their production processes and transit towards higher valueadded activities in the value chain (HKTDC, 2017b: 3). Or, through automation and other productivity-enhancing methods, to push the value curve upwards. The move to higher value-added activities also fits well with more recent accounts of China becoming an innovation powerhouse (Choudhury, 2017; Veugelers, 2017).

These developments raise several questions on the operation of supply chains, the most obvious being China's increasingly dominant role. For China's supply chain

1 HKTDC (2017a: 4) gave an account of a Hong Kong company specialised in plastic injection moulding establishing a manufacturing operation in Vietnam, only to find lower skills among Vietnamese workers compared to those in South China. Vietnam's lack of supporting industries such as precision tool-making and engineering support has forced the company to source services from China.

2 Koopman, Wang and Wei (2008) estimated that domestic content accounts for no more than half of China's manufactured exports, even less (just 18\%) of its processed exports.

3 Li (2018) reported China's royalty payments for intellectual property being over twenty times its receipts. 
partners, a key question is what are the implications of their roles in these chains, and how dependent are they on China in terms of inputs or outputs? These are the questions this paper seeks to explore.

In the following section, we chart briefly China's technological progress over the last decade that shaped the country's new image in technology. This progress is framed against its increasing dominance in controlling global supply chains that end in China. In the section that follows, evidence is found in which China's technological advances have implications for other participants of its supply chains in terms of intermediate inputs and value addition of supply chain activities. Implications for ASEAN's middle-income countries that are no match for China's technological prowess are briefly discussed in the conclusion.

\section{China, Domestic Innovation and Global Supply Chains}

Much has changed since the beginning of this decade and the case of China is shown by the metrics in Table 1. In confirming these metrics, Harris (2018) also showed the number of science and engineering graduates that increased from 359,000 to 1.65 million between 2000 and 2014, far outpacing the number of US graduates which rose from 483,000 to 742,000 . By about 2015, science and technology data for China have shown the country to have closed in on its counterparts in the US and Europe. Thus, China's gross expenditure on research and development (GERD) is higher than that in

Table 1. Selected indicators of China's science and technology capability

\begin{tabular}{|c|c|c|c|c|}
\hline Indicator & Units & US & EU28 & China \\
\hline $\begin{array}{l}\text { Gross domestic } \\
\text { product }\end{array}$ & $\begin{array}{l}\text { Trillion purchasing power parity } \\
\text { (US\$) in } 2016\end{array}$ & $\begin{array}{r}18.5 \\
(2014)\end{array}$ & $\begin{array}{r}20.3 \\
(2015)\end{array}$ & 21.4 \\
\hline $\begin{array}{l}\text { Gross expenditure } \\
\text { on research and } \\
\text { development share }\end{array}$ & $\begin{array}{l}\% \text { of Organisation for Economic } \\
\text { Co-operation and Development } \\
\text { in } 2015\end{array}$ & $\begin{array}{r}29.1 \\
(2018)\end{array}$ & $\begin{array}{r}21.7 \\
(2014)\end{array}$ & 23.7 \\
\hline No. of researchers & '000 in 2014 & $\begin{array}{r}1,352 \\
(2011)\end{array}$ & $\begin{array}{r}1,759 \\
(2020)\end{array}$ & 1,524 \\
\hline $\begin{array}{l}\text { PhDs in science \& } \\
\text { engineering }\end{array}$ & In 2012 & 35,360 & 58,541 & 32,331 \\
\hline Paper share & \% of world in 2013 & 22.0 & 30.0 & 13.0 \\
\hline Patents & \% applications in 2014 & 53,318 & 51,587 & 25,834 \\
\hline Citations & Average relative citations in 2012 & 1.43 & 1.19 & 0.86 \\
\hline $\begin{array}{l}\text { High-tech } \\
\text { manufacturing }\end{array}$ & World share in 2014 , value added & $\begin{array}{r}28.7 \\
(2015)\end{array}$ & $\begin{array}{r}17.0 \\
(2010)\end{array}$ & 27.3 \\
\hline High-tech exports & World share in 2014 , cash basis & $\begin{array}{r}12.4 \\
(2003)\end{array}$ & $\begin{array}{r}18.3 \\
(2006)\end{array}$ & 24.0 \\
\hline
\end{tabular}

Source: Basu, Foland, Holdridge and Shelton (2018), Table 1. 
Europe, and closing in on the US share. The number of researchers is higher than in the US though below that of Europe. In addition, a survey by Nikkei and Elsevier (Okoshi, 2019) placed China in the top $75 \%$ of the most important fields in science, leaving the US with the remaining 25\%. The announcement of "Made in China 2025" with state support for China's economic model to move from quantity to quality, and focusing on 10 strategic industries representing nearly $40 \%$ of China's entire industrial value-added manufacturing is a clarion call for domestic innovation.

How would the global supply chains dominated by China be affected by the country's advancing technology? Chapter 9 of the 2015 Asia Pacific Trade and Investment Report (APTIR2015) of UNESCAP (p. 147) argued that advancing technology would permit China to take over higher value-added processes along the supply chain as well as shift the entire chain upwards with enhanced productivity.

This is clearly occurring for China, which "has developed a mature supply chain as well as highly efficient logistics and supporting services, and is moving gradually from labour-intensive processing activities to high value-added industries" (HKTDC, 2017c, Conclusions and Recommendations, p. 1). Growing technological capability would also allow China to produce more of the intermediate goods used in the supply chains (Lund et al., 2019: 65). As labour costs in China rise, domestically constituted supply chains will see fit to outsource assembly operations - just like the MNCs before them - to lower-cost Southeast Asian countries at the low-cost segments of the supply chain.

However, China's technological advances will leave behind those members of the supply chain unable to keep up with China. For these countries, the APTIR2015 admitted of the possibility that "a country might join a global value chain at a low valueadded point and become stuck there. Instead of moving up the value chain, it would experience stagnating productivity and income growth" (p. 147).

Table 2. Science and technology indicators - China vs. ASEAN-6 countries

\begin{tabular}{|c|c|c|c|c|c|c|c|}
\hline $\begin{array}{l}\text { Science and } \\
\text { technology indicators }\end{array}$ & China & $\begin{array}{l}\text { Indo- } \\
\text { nesia }\end{array}$ & $\begin{array}{l}\text { Malay- } \\
\text { sia }\end{array}$ & $\begin{array}{l}\text { Philip- } \\
\text { pines }\end{array}$ & $\begin{array}{l}\text { Singa- } \\
\text { pore }\end{array}$ & $\begin{array}{l}\text { Thai- } \\
\text { land }\end{array}$ & $\begin{array}{l}\text { Viet- } \\
\text { nam }\end{array}$ \\
\hline $\begin{array}{l}\text { Technological readiness } \\
\text { subindex } 2017 / 8\end{array}$ & 73 & 80 & 46 & 83 & 14 & 61 & 79 \\
\hline $\begin{array}{l}\text { Innovation subindex } \\
2017 / 8\end{array}$ & 28 & 31 & 22 & 65 & 9 & 50 & 71 \\
\hline $\begin{array}{l}\text { Medium- and high-tech } \\
\text { value added \% in total } \\
\text { manufacturing } 2015\end{array}$ & 58.8 & 35.1 & 42.6 & 46.0 & 80.4 & 40.7 & 40.4 \\
\hline $\begin{array}{l}\text { R\&D expenditure as } \\
\% \text { of GDP } 2016\end{array}$ & 2.1 & 0.2 & 1.4 & $\begin{array}{c}0.2 \\
(2015)\end{array}$ & 2.2 & 0.8 & $\begin{array}{c}0.4 \\
(2015)\end{array}$ \\
\hline $\begin{array}{l}\text { Patent applications by } \\
\text { residents } 2016\end{array}$ & $1,204,981$ & 1,101 & 1,109 & 327 & 1,601 & 1,098 & 560 \\
\hline
\end{tabular}

Sources: WEF: Global Competitiveness Report, 2017-18; UNIDO: Industrial development report 2018; World Bank: World development indicators. 
The middle-income countries in ASEAN appear caught in this predicament. As Table 2 shows, science and technology indicators for China are, with a few minor exceptions, well ahead of those in ASEAN countries with the exception of Singapore. Although not shown in the table, China's advance, reflected in these indicators, is also occurring much faster.

Does evidence exist of a low productivity trap in ASEAN? How may it unfold as China strengthens its hold on global supply chains while developing its own supply chains to cater to growing domestic market demand? An obvious consequence is to witness the comparative advantage of high-tech exports and of exports embodying technology shifting to China. With China able to produce more of its own intermediate goods, one may also see more intermediate goods sourced from China in the intermediate imports of ASEAN countries participating in supply chains. And third, as China captures more value added, the share of value added captured by ASEAN countries will diminish. Are these developments borne out in practice?

\section{Supply Chains and Comparative Advantage - ASEAN vs. China}

The data base useful for ascertaining the above trends is the Trade in Value Added (TIVA) Database of the Organisation for Economic Co-operation and Development (OECD). The data estimates the "value added by each country in the production of goods and services that are consumed worldwide" (http://www.oecd.org/sti/ind/ measuring-trade-in-value-added.htm). The latest edition is the 2018 edition which is used here.

Table 3 shows the bilateral revealed comparative advantages (RCAs) between the ASEAN- 6 countries and China with respect to primary commodities and manufactured goods. Comparing the RCAs of these exports show that the RCAs favour heavily primary commodity exports from year 2000 until the present day (2016). While manufactured goods exports had RCAs greater than one for Indonesia, Malaysia, the Philippines and Singapore in year 2000, all RCA values for manufactured exports had deteriorated by 2016, Vietnam being the singular exception.

This performance, with primary commodities enjoying continued comparative advantage in exports to China and manufactured exports not standing out despite years of export orientation speaks to a lack of technological capability among ASEAN nations. Beyond this, researchers have worried about "premature deindustrialisation" among ASEAN countries, in which industrial competitiveness begin to decline even before the industrial sector reaches maturity. The most obvious example is Malaysia where Rasiah (2011) blamed the government's ethnic policies for failing to stimulate industrial transition to high value-added activities, a view echoed by Menon and Ng (2015) who referred to Malaysia's "policy-induced premature deindustrialisation". Indonesia's Institute for the Development of Economics and Finance (INDEF) came to a similar conclusion but pointed the finger at the service sector's greater readiness to support foreign as opposed to local manufacturing (Pebrianto, 2017). Thailand has focused on agricultural technology rather than on manufacturing ("How is Thailand", 2019). As China takes the global lead in some sectors, Sender (2020) and West (2018, p. 21) opined that ASEAN countries are all caught in a "middle-income trap". 
Table 3. Bilateral RCAs: ASEAN-6 with China, 2000-2016

\begin{tabular}{lcccccc}
\hline Year 2000 & $\begin{array}{c}\text { Indo- } \\
\text { nesia }\end{array}$ & $\begin{array}{c}\text { Malay- } \\
\text { sia }\end{array}$ & $\begin{array}{c}\text { Philip- } \\
\text { pines }\end{array}$ & $\begin{array}{c}\text { Singa- } \\
\text { pore }\end{array}$ & $\begin{array}{c}\text { Thai- } \\
\text { land }\end{array}$ & $\begin{array}{c}\text { Viet- } \\
\text { nam }\end{array}$ \\
\hline Manufactured goods (6) & 1.12 & 1.68 & 3.99 & 1.22 & 0.82 & 0.24 \\
Machinery \& transport equipment (7) & 0.17 & 0.71 & 0.72 & 0.87 & 0.81 & 0.06 \\
Animal and vegetable oils \& fats (4) & 1.94 & 3.24 & 1.72 & 0.51 & 0.84 & 1.43 \\
Crude materials (2) & 2.38 & 3.39 & 3.03 & 2.83 & 3.95 & 3.55 \\
Mineral fuels (3) & 1.46 & 1.14 & 8.22 & 1.61 & 5.12 & 2.04 \\
\hline Year 2016 & Indo- & Malay- & Philip- & Singa- & Thai- & Viet- \\
& nesia & sia & pines & pore & land & nam \\
\hline Manufactured goods (6) & 1.01 & 0.68 & 0.23 & 0.81 & 0.57 & 1.11 \\
Machinery \& transport equipment (7) & 0.21 & 1.10 & 1.05 & 1.09 & 0.61 & 0.76 \\
Animal and vegetable oils \& fats (4) & 1.28 & 0.93 & 0.28 & 0.44 & 0.46 & 0.94 \\
Crude materials (2) & 1.79 & 3.35 & 2.69 & 1.96 & 4.59 & 4.04 \\
Mineral fuels (3) & 1.64 & 0.67 & 3.98 & 0.61 & 1.31 & 3.36 \\
\hline
\end{tabular}

Note: Numbers in parentheses are commodity codes (SITC classification Rev 3; level 1).

While deindustrialisation is a long-term threat, the fact that China's growing appetite for resources has seen RCAs for primary commodities soar at the expense of manufactures has allayed ASEAN countries' fears (Kwan, 2004). But as China's economy rebalances towards consumption and higher quality growth, this continued growth cannot be guaranteed and ASEAN's loss of comparative advantage will hit home.

The TIVA database contains data on domestic value added of all exports. This permits understanding of whether the domestic economy is able to create more value in its exports over time, such creation being a hallmark of success in a country's industrial development. From the perspective of global supply chains, an increase in domestic value added also means the country's ability to engage in more value-added activities in the chain.

Table 4 shows the share of domestic value added in each country's exports of manufactured goods and the more high-tech group "computers, electronics and electrical equipment" which are major parties to global supply chains. In the case of manufactured goods, domestic value added account for about half the value of total exports for Malaysia, Singapore, Thailand and Vietnam, while Indonesia's share at $80 \%$ and above and the Philippines' share at $60 \%$ and above are highest. Looking intertemporally over the last decade (2005-2015), there has been a modest gain in domestic value added for all countries except Singapore and Vietnam.

For computers, etc., the domestic value added share of exports is much lower than for manufactured goods exports for Indonesia, Malaysia, Thailand and Vietnam but remained roughly the same for Singapore and Thailand. Malaysia and Vietnam also had the lowest share of domestic value added. For these countries, participation 
Table 4. Share of domestic value added in total exports of manufactures and computers, electronics and electrical equipment, ASEAN-6, 2005-2015

\begin{tabular}{lcccccc}
\hline Manufactured goods & Indonesia & Malaysia & Philippines & Singapore & Thailand & Vietnam \\
\hline 2005 & 76.4 & 43.1 & 58.7 & 53.9 & 51.3 & 55.4 \\
2006 & 79.5 & 45.1 & 54.9 & 49.3 & 52.4 & 53.6 \\
2007 & 79.8 & 44.5 & 61.3 & 55.7 & 53.1 & 50.1 \\
2008 & 79.6 & 48.2 & 61.4 & 49.6 & 49.2 & 50.2 \\
2009 & 82.8 & 47.3 & 65.2 & 53.5 & 54.5 & 55.2 \\
2010 & 82.4 & 45.8 & 63.7 & 53.8 & 54.8 & 51.9 \\
2011 & 82.1 & 47.3 & 66.1 & 50.4 & 50.8 & 50.6 \\
2012 & 82.2 & 48.6 & 63.5 & 51.9 & 53.7 & 50.5 \\
2013 & 81.2 & 49.6 & 67.5 & 52.2 & 54.2 & 51.7 \\
2014 & 82.5 & 51.0 & 68.6 & 51.3 & 56.1 & 51.1 \\
2015 & 85.0 & 51.2 & 65.0 & 53.3 & 59 & 50.0 \\
\hline Computers, electronics, & Indonesia & Malaysia & Philippines & Singapore & Thailand & Vietnam \\
electric equipment & & & & & & \\
\hline 2005 & 63.3 & 33.8 & 56.2 & 58.6 & 43.9 & 52.9 \\
2006 & 66.5 & 36.7 & 52.7 & 52.4 & 43.4 & 48.8 \\
2007 & 65.5 & 35.5 & 58.5 & 61.2 & 45.6 & 46.1 \\
2008 & 59.1 & 38.6 & 59.4 & 55.2 & 44.2 & 45.9 \\
2009 & 64.9 & 38.3 & 62.9 & 61.6 & 47.3 & 49.6 \\
2010 & 63.8 & 38.0 & 60.0 & 59.7 & 46.5 & 47.2 \\
2011 & 63.1 & 39.2 & 64.2 & 54.1 & 43.1 & 45.3 \\
2012 & 62.2 & 41.5 & 61.2 & 56.4 & 47.3 & 41.6 \\
2013 & 64.8 & 42.9 & 65.4 & 56.8 & 48.2 & 41.6 \\
2014 & 65.4 & 43.6 & 66.7 & 55.2 & 49.0 & 41.4 \\
2015 & 70.0 & 44.1 & 63.0 & 56.0 & 51.8 & 38.8 \\
\hline
\end{tabular}

Source: OECD, TIVA database.

in global supply chains has not produced as much value added as in other ASEAN countries despite their higher proportions of high-tech exports. Perhaps, location of supply chains in these countries is mainly to take advantage of cheap labour (Vietnam) or cheap imported labour (Malaysia). Also of interest is that fact that over the decade, the share of domestic value added rose only slightly in Indonesia, the Philippines and Thailand, but actually declined for Singapore and Vietnam, the latter from 53\% to $39 \%$ in a decade. These figures hardly inspire confidence in value-added capture by ASEAN countries through their respective supply chains.

ASEAN's manufacturing supply chains are constrained by stagnant technological capability leaving them unable to develop their own supply chains. However, ASEAN retains advantages in areas like palm oil R\&D and should adopt a strategy to develop the related supply chains. 
The growing importance of China in supply chains should see its presence in different areas of the supply chain. For instance, one might see more Chinese inputs among intermediate goods imports. This is shown in Table 5, which displays the proportions of Chinese inputs among intermediate goods imported in each country's gross exports in ASEAN-6. The most striking feature of these data has been the significant growth of Chinese inputs among intermediate goods imports for every country with the exception of Singapore. For the other five countries, Chinese inputs accounted for little more than $5 \%$ of intermediate goods imports in 2005 . Ten years later, the share has doubled to more than $10 \%$, the increase occurring from about 2012. Each country has seen a doubling of the share of Chinese inputs in a decade. Vietnam's increase has been particularly notable, its share rising from $11.3 \%$ in 2005 to $25 \%$ in 2015 . This may reflect the location of Chinese originated supply chains in Vietnam.

How does China's inputs compare with inputs from other countries? This is shown in Table 6 which includes inputs not only from China but Japan, South Korea, Taiwan and the US. For 2005, inputs from these five countries account for roughly $30 \%$ of intermediate goods imports in the gross exports of Malaysia, the Philippines and Thailand, but only $20 \%$ and below for Indonesia and Singapore and nearly $40 \%$ for Vietnam. Among international inputs, China did not loom large; indeed, for Malaysia, Japan and the US were the top sources of international inputs. The same is true for the Philippines where China's share was a miniscule $0.3 \%$. Only in Vietnam was China the top source, together with Taiwan.

A decade later, much has changed. With the exception of Singapore, China is the most important source of foreign input among intermediate goods imports (Table 6). While the share of international inputs used for exports have remained largely the same between 2005 and 2015, China has come to account for up to half of all foreign inputs used for exports.

Table 5. Share of Chinese inputs among intermediate goods imports in gross exports, ASEAN-6, 2005-2015

\begin{tabular}{rcccccc}
\hline Year & Indonesia & Malaysia & Philippines & Singapore & Thailand & Vietnam \\
\hline 2005 & 5.3 & 7.0 & 4.3 & 1.7 & 6.1 & 11.3 \\
2006 & 5.4 & 7.3 & 5.1 & 2.3 & 6.1 & 12.2 \\
2007 & 6.0 & 8.2 & 4.3 & 2.2 & 6.6 & 16.1 \\
2008 & 6.2 & 7.9 & 4.9 & 2.0 & 6.7 & 16.4 \\
2009 & 7.0 & 8.2 & 4.9 & 2.3 & 6.6 & 18.2 \\
2010 & 7.2 & 7.7 & 4.7 & 2.0 & 7.4 & 17.8 \\
2011 & 7.5 & 8.4 & 7.2 & 2.2 & 8.4 & 18.4 \\
2012 & 8.8 & 10.2 & 6.9 & 2.3 & 9.8 & 19.2 \\
2013 & 9.4 & 11.8 & 8.7 & 2.6 & 9.9 & 22.4 \\
2014 & 10.4 & 12.2 & 10.2 & 2.7 & 11.3 & 23.8 \\
2015 & 12.5 & 13.4 & 12.0 & 2.9 & 12.1 & 25.8 \\
\hline
\end{tabular}

Source: OECD, TIVA database. 
Table 6. Percentage share of international inputs among intermediate goods imports in gross exports, ASEAN-6, 2005 and 2015

\begin{tabular}{llrrrrrr}
\hline Year & $\begin{array}{l}\text { Foreign country } \\
\text { input }\end{array}$ & Indonesia & Malaysia & Philippines & Singapore & Thailand & Vietnam \\
\hline 2005 & & & & & & \\
& China & 5.3 & 7.0 & 0.3 & 1.7 & 6.1 & 11.3 \\
& Taiwan & 1.6 & 3.7 & 6.0 & 1.4 & 2.7 & 11.0 \\
& Japan & 5.9 & 8.1 & 10.2 & 5.4 & 12.5 & 7.2 \\
& South Korea & 3.5 & 3.4 & 3.7 & 1.3 & 2.8 & 8.5 \\
& US & 3.9 & 8.2 & 12.0 & 8.6 & 5.0 & 1.8 \\
\hline \multirow{2}{*}{2015} & 20.2 & 30.4 & 32.2 & 18.4 & 29.1 & 39.8 \\
\hline Total & 12.5 & 13.4 & 12.0 & 2.9 & 12.1 & 25.8 \\
& China & 1.2 & 2.9 & 4.3 & 1.8 & 1.8 & 4.6 \\
& Taiwan & 4.7 & 4.5 & 4.8 & 6.5 & 7.1 & 5.4 \\
& Japan & 3.9 & 2.9 & 3.8 & 1.9 & 2.2 & 11.8 \\
& South Korea & 3.3 & 5.2 & 6.0 & 8.4 & 3.5 & 3.1 \\
\hline US & 25.6 & 28.9 & 30.9 & 21.5 & 26.7 & 50.7 \\
\hline & & & & & & \\
\hline
\end{tabular}

Source: OECD, TIVA database.

The growing importance of Chinese inputs suggests not only China's ability to take over an increasing part of supply chains in this region but also raises the possibility that it is able to establish its own supply chains that are linked to Southeast Asia. Whether ASEAN countries participate in those segments of the chains with more value addition will depend on these countries' technological capabilities. However, ASEAN countries may become more dependent on Chinese technology if China's strategy is to use foreign direct investment (FDI) to export its technology.

\section{Conclusion}

Much of the literature on global supply chains that emerged from production fragmentation as an innovation assumes the construction of these chains by multinational corporations from advanced countries to take advantage of cost advantages in other, typically developing countries and reduce production costs. In this world of global supply chains, the corporations that developed and control them are from the first world, garnering much of the value added upstream (R\&D, product design) as well as downstream (branding, marketing) along these chains. To the extent developing countries are participants in these chains, they have no say in how these chains are constituted and who exercise responsibility over different parts of the chains. Almost without exception, developing country players are relegated to the low value added, assembly operations parts of the chains. The story in the making of the iPhone is a graphic illustration of this system. 
However, this system has undergone major changes. First, with the rise of multinational corporations in Asia like Sony and Samsung, the world of global supply chains is no longer the exclusive domain of companies in the developed West. Emerging Asia, and especially China, is building domestic supply chains, which are increasingly located from start to finish in Asia (Lund et al., 2019, p. 68). ASEAN will become a new base for Chinese manufacturing as China's enterprises are looking to invest abroad especially to re-orientate the manufacturing supply chains towards ASEAN countries in the region ("Supply chains", 2019). Secondly, China's ascendancy as "factory to the world" and its still growing domestic market has endowed its industrial clusters like the Pearl River Delta with unmatched competitiveness through agglomeration and logistics support, rendering them the natural end-points for many supply chains. Finally, the rise of China as a technological powerhouse, apart from its other competitiveness advantages cited above, has changed the equation of which supply chain segment possesses the technology and captures value added. ${ }^{4}$ This has implications not only for advanced countries which are accustomed to capturing the bulk of value added, but also for other participants of supply chains which China increasingly dominates.

In this paper, the focus has been on middle-income countries of ASEAN, all of which are participants of the above supply chains with China. Evidence exists of China's growing importance in these supply chains in terms of: (1) restraining any gains in comparative advantage in ASEAN countries' exports to China of manufactured goods that embody technology, (2) as well as of any capture of value added in ASEAN's exports of manufactured goods and of computers, electronics and electric equipment to China, (3) the increase in China-sourced inputs in intermediate goods inputs used for exports, and (4) China's growing dominance as a source of intermediate goods inputs.

The implications for ASEAN countries lagging increasingly behind China are ominous. Not only are the opportunities for industrial upgrading limited and chances of catch-up remote, but also prospects for greater value addition through supply chain activities are modest. This means that due to absent upgrading, ASEAN-located segments of supply chains will not embody much value added in their activities, being relegated to relatively labour intensive tasks, regardless of who controls these supply chains. The case of the Hong Kong company relocating to Vietnam having to continue to source some of its services back in South China because of the lack of the requisite skills in Vietnam is a stark reminder of the limits to ASEAN countries' ability to benefit from even China sourced supply chains.

\section{References}

Akamatsu, K. (1962). A historical pattern of economic growth in developing countries. Journal of Developing Economies, 1(s1), 3-25. https://doi.org/10.1111/j.1746-1049.1962.tb01020.x

Basu, A., Foland, P., Holdridge, G., \& Shelton, R.D. (2018). China's rising leadership in science and technology: Quantitative and qualitative indicators. Scientometrics, 117, 249-269. https://doi. org/10.1007/s11192-018-2877-5

4 In 2017, Apple CEO Tim Cook spoke of “(China's) highly skilled software developers developing apps for the App Store" and "the depth of highly skilled labour in the manufacturing space" as the reasons why Apple continues to make its iPhones there (Leibowitz, 2017). 
Cheong, K.C., Wong, C.Y., \& Goh, K.L. (2016). Technology catch-up with Chinese characteristics: What can Southeast Asia learn from China? The Round Table, 105(6), 667-681. https://doi. org/10.1080/00358533.2016.1246853

Choudhury, S.R. (2017, July 18). Reporter's notebook: China is shedding its copycat image with innovation after innovation. CNBC. Retrieved April 15, 2019 from https://www.cnbc.com/ 2017/07/18/china-emerging-as-a-tech-and-innovation-powerhouse.html

Cimoli, M., Dosi, G., \& Stiglitz, J. (2009). Industrial policy and development: The political economy of capabilities accumulation. Oxford: Oxford University Press.

Economist. (2018, October 11). China's grip on electronics will be hard to break. Retrieved April 11, 2019 from https://www.economist.com/business/2018/10/11/chinas-grip-on-electronicsmanufacturing-will-be-hard-to-break

Gereffi, G., \& Lee, J. (2012). Why the world suddenly cares about global supply chains. Journal of Supply Chain Management, 48(3), 24-32. https://doi.org/10.1111/j.1745-493X.2012.03271.x

Gerschenkron, A. (1962). Economic backwardness in historical perspective. Cambridge, MA: Harvard University Press.

Harris, B. (2018, February 7). China is an innovation superpower. This is why. World Economic Forum. Retrieved April 11, 2019 from https://www.weforum.org/agenda/2018/02/thesecharts-show-how-china-is-becoming-an-innovation-superpower/

Hong Kong Trade Development Council (HKTDC). (2017a, October 10). Rapid development of Asia's electronics supply chain. HKTDC Research.

Hong Kong Trade Development Council (HKTDC). (2017b, October 13). Evolving role of 'made in China'. HKTDC Research.

Hong Kong Trade Development Council (HKTDC). (2017c, October 20). Shift of Global Supply Chain and Guangdong-Hong Kong Industrial Development (Conclusions and Recommendations). HKTDC Research.

How is Thailand bringing technology to the table? (2019, July 29). Thailand Business News. Retrieved May 31, 2020 from https://www.thailand-business-news.com/tech/75088-how-isthailand-bringing-technology-to-the-table.html

Kim, L. (1997). Imitation to innovation: The dynamics of Korea's technological learning (management of innovation and change). Boston, MA: Harvard Business School Press.

Koopman, R., Wang, Z., \& Wei, S.J. (2008). How much of Chinese exports is really made in China? Assessing domestic value-added when processing trade is pervasive (NBER Working Paper, No. 14109). Cambridge, MA: National Bureau of Economic Research. https://doi. org/10.3386/w14109

Kwan, C.H. (2004). China's rise pressures ASEAN to make industrial adjustments - industrial upgrading or deindustrialization. China in Transition (Research Institute of Economy Trade and Industry, Tokyo). Retrieved April 14, 2019 from https://www.rieti.go.jp/en/china/ 04012601.html

Lee, K., \& Lim, C. (2001). Technological regimes, catch-up and leapfrogging: Findings from the Korean industries. Research Policy, 30(3), 459-483. https://doi.org/10.1016/S00487333(00)00088-3

Leibowitz, G. (2017, December 21). Apple CEO Tim Cook: This is the No. 1 reason we make iPhones in China (it's not what you think). Inc. Retrieved April 15, 2019 from https://www. inc.com/glenn-leibowitz/apple-ceo-tim-cook-this-is-number-1-reason-we-make-iphones-inchina-its-not-what-you-think.html

Li, Y. (2018, August 3). Understanding China's technological rise. The Diplomat. Retrieved April 11, 2019 from https://thediplomat.com/2018/08/understanding-chinas-technological-rise/

Lund, S., Manyika, J., Woetzel, J., Bughin, J., Krishnan, M., Seong, J., \& Muir, M. (2019). Globalization in transition: The future of trade and value chains. Washington DC: McKinsey Global Institute. 
Menon, J., \& Ng, T. (2015, October 1). Policy-induced premature deindustrialization in a highincome aspirant: Malaysia. VOX. Retrieved April 14, 2019 from https://voxeu.org/article/ policy-driven-premature-deindustrialisation-malaysia

Okoshi, Y. (2019, January 6). China research papers lead the world in cutting-edge tech. Nikkei Asian Review. Retrieved April 18, 2019 from https://asia.nikkei.com/Business/China-tech/ China-s-research-papers-lead-the-world-in-cutting-edge-tech

Organisation for Economic Co-operation and Development (OECD). (2018). Trade in value added (TiVA). Retrieved from http://www.oecd.org/sti/ind/measuring-trade-in-value-added.htm

Pebrianto, F. (2017, February 9). Indonesia experiences early deindustrialization: Indef. Tempo. Retrieved September 15, 2020 from https://en.tempo.co/read/844902/indonesia-experiencesearly-deindustrialization-indef

Perez, C., \& Soete, L. (1988). Catching up in technology: Entry barriers and windows of opportunity. In G. Dosi, C. Freeman, R. Nelson \& L. Soete (Eds.), Technical change and economic theory (pp. 458-479). New York, NY: Pinter.

Rasiah, R. (2011). Is Malaysia facing negative deindustrialization? Pacific Affairs, 84(4), 714-735. https://doi.org/10.5509/2011844715

Rostow, W.W. (1960). The stages of economic growth: A non-communist manifesto. Cambridge: Cambridge University Press. https://doi.org/10.1017/СBO9780511625824

Sender, H. (2020, January 14). In technology, where China leads, the rest of the world follows. Nikkei Asian Review. Retrieved May 31, 2020 from https://asia.nikkei.com/Spotlight/ Comment/In-technology-where-China-leads-the-rest-of-the-world-follows

Supply chains re-routed to ASEAN. (2019, June 25). The Nation Thailand. Retrieved May 31, 2020 from https://www.nationthailand.com/business/30371749

Stevenson, A. (2018, September 24). Trump's tariffs may hurt, but quitting China is hard to do. New York Times. Retrieved April 11, 2019 from https://www.nytimes.com/2018/09/24/ business/china-tariffs-manufacturing-cambodia.html

United Nations Economic and Social Commission for Asia and the Pacific (UNESCAP). (2015). Global value chains, technology transfers and innovation. In Asia Pacific trade and investment report 2015: Supporting participation in value chains (Chapter 9, pp. 149-163). Bangkok: Author.

United Nations Industrial Development Organization (UNIDO). (2017). Industrial development report 2018. Demand for manufacturing: Driving inclusive and sustainable industrial development. Vienna: Author.

Veugelers, R. (2017, August 30). China is the world's new science and technology powerhouse. Breugel. Retrieved April 15, 2019 from http://bruegel.org/2017/08/china-is-the-worlds-newscience-and-technology-powerhouse/

West, J. (2018). Asian century... on a knife edge: A 360 degree analysis of Asia's recent economic development. Singapore: Palgrave MacMillan. https://doi.org/10.1007/978-981-10-7182-9

World Bank, World development indicators.

World Economic Forum (WEF). (2017). The global competitiveness report, 2017-18. Geneva, Switzerland: Author. 